\title{
Methodology for Assessing External Costs in the Energy Industry
}

\section{Introduction}

Externalities and their costs are incurred when negative social and economic activities of some party have an impact on others and this impact is not offset by expenditures to liquidate it. For example, in the electric power industry, external costs are generated when electricity producers do not incur expenditures required to liquidate adverse effects of their actions that are borne by another party. When a producer bears these expenditures, they are transformed into direct costs and are thus no longer external costs. They constitute components of direct manufacturing costs in the same way as other production costs [10, p. 58].

External effects should be the subject of detailed studies taking into account the public nature of environmental goods and the consequent absence of prices for many elements of the natural environment. The dominance of short-term financial objectives in development strategies of many companies, leading to overexploitation of the natural environmental and production of negative goods in the form of reduced social benefits, expressed as a reduction of current or future social welfare, indicate the desirability of such research.

Taking this into account, this article presents methodologies for assessing external costs in the energy industry.

\section{Classification and valuation methods for externalities in the electric power industry}

External costs in the electric power industry are usually associated with environmental pollution and the resulting direct and indirect losses. Estimation of

* AGH University of Science and Technology, Department of Energy Management, Faculty of Management. 
external costs is difficult because of complicated cause and effect relationships, particularly in the effect of low concentrations of pollutants on the natural environment and the quality of human life.

In simple economic efficiency analyses of electricity generation processes, it is assumed that the analyzed project is completely independent, i.e. it has no effect on any other business activities or the natural environment. This is a gross oversimplification. Electricity generation produces numerous external effects.

The issue of determining external costs remains controversial. Due to the lack of consensus (in literature) on the proper method for calculating and accounting external costs in economic calculations, determining their level for every generating technology is currently not possible. To assess these costs, it is necessary to classify externalities and indirect methods for their valuation as well as to develop a list of information required to determine the external and social costs of electricity generation. Such a classification of external effects is shown in Table 1.

Table 1

Classification of externalities in electricity generation

\begin{tabular}{|l|l|}
\hline \multicolumn{1}{|c|}{ Feature } & \multicolumn{1}{c|}{ Characteristics } \\
\hline Nature & $\begin{array}{l}\text { - External, negative effects resulting from the use of environmen- } \\
\text { tal resources in the process of generating electricity. }\end{array}$ \\
\hline Causes & $\begin{array}{l}\text { - The public nature of environmental goods (since they are free } \\
\text { goods) and the absence of prices for many elements of the nat- } \\
\text { ural environment. } \\
\text { - The dominance of short-term financial objectives in companies' } \\
\text { development strategies. } \\
\text { - Overexploitation of the natural environment and the produc- } \\
\text { tion of pollutants (negative goods). }\end{array}$ \\
\hline Measure & $\begin{array}{l}\text { - Reduced social benefits, expressed as a reduction of current and } \\
\text { future social welfare. The units are: costs, revenue and utility. }\end{array}$ \\
\hline Timeframe & $\begin{array}{l}\text { - Ex ante - ecological risk. } \\
\text { - Expost - environmental damage. }\end{array}$ \\
\hline Type of loss & $\begin{array}{l}\text { - Damage to individual (private negative goods). } \\
\text { - Social damage (group "victims", public negative goods). }\end{array}$ \\
\hline Impact & $\begin{array}{l}\text { - Cumulative losses. } \\
\text { - Synergistic loss. }\end{array}$ \\
\hline Way of expressing & $\begin{array}{l}\text { - Losses to property (assets). } \\
\text { - Losses in health. } \\
\text { - Loss of production capacity of the natural environment. }\end{array}$ \\
\hline
\end{tabular}


Tabela 1 cont.

\begin{tabular}{|l|l|}
\hline $\begin{array}{l}\text { Impact on } \\
\text { national income }\end{array}$ & $\begin{array}{l}\text { - Losses in streams of goods and services - the potential deple- } \\
\text { tion of national income. } \\
\text { - Losses in environmental assets ("depreciation" of the natural } \\
\text { environment). }\end{array}$ \\
\hline Range of subjects & $\begin{array}{l}\text { - Loss of physical and financial capital. } \\
\text { - Loss of human capital. } \\
\text { - Loss of natural capital (renewable and nonrenewable). }\end{array}$ \\
\hline $\begin{array}{l}\text { Places where } \\
\text { losses occur (links } \\
\text { in the business } \\
\text { processes) }\end{array}$ & $\begin{array}{l}\text { - Losses in production, consumption, distribution and retail. } \\
\text { - Losses in the economy, natural environment, society. }\end{array}$ \\
\hline $\begin{array}{l}\text { The possibility } \\
\text { and method of } \\
\text { valuation }\end{array}$ & $\begin{array}{l}\text { - Direct losses. } \\
\text { - Technological losses. } \\
\text { - Non-market losses. } \\
\text { - Financial losses. }\end{array}$ \\
\hline $\begin{array}{l}\text { Areas of } \\
\text { the natural } \\
\text { environment }\end{array}$ & $\begin{array}{l}\text { - Losses in the water. } \\
\text { - Losses on the ground. } \\
\text { - Losses in the biosphere (atmosphere, hydrosphere). } \\
\text { - Losses due to waste (solid, water and sewage, toxic and chemi- } \\
\text { cal waste, hazardous waste). }\end{array}$ \\
\hline $\begin{array}{l}\text { - Climate change. } \\
\text { on losses }\end{array}$ & $\begin{array}{l}\text { - Depletion of the ozone layer. } \\
\text { - Water and soil acidification. } \\
\text { - Poisoning of water and soil with toxic chemicals. } \\
\text { - Solid waste. } \\
\text { - Soil degradation (desertification and erosion). } \\
\text { - Consumption of non-renewable mineral resources and energy. } \\
\text { - Damage to biodiversity. } \\
\text { - Destruction of the landscape. } \\
\text { - Damage to forest ecosystems and water. }\end{array}$ \\
\hline
\end{tabular}

Source: based on [4, pp. 76-77].

The four main areas of the natural environment in which losses occur are: in the water, on the surface of the earth, in the biosphere and those associated with solid waste. Emissions of harmful substances in the production of electricity, such as nitrogen and sulfur oxides, particulates, mercury and other solid waste, including radioactive waste, can be relatively easily quantified in physical units, but the valuation the damage they cause is much more difficult. 
Due to the lack of demand and (consequently) a market mechanism for valuing potential losses to the natural environment as a result of electricity generation, it becomes necessary to use indirect methods (Table 2). These methods are based on an attempt at market valuation of losses, the cost of substitutes for threatened or lost property, replacement or prevention costs, compensation or determination of lost opportunities.

Table 2

Indirect methods for valuation of potential losses to the natural environment caused by electricity generation

\begin{tabular}{|c|c|}
\hline Method & Basis for valuation \\
\hline Dose-response method & $\begin{array}{l}\text { Based on the use of dose-response functions or dose-re- } \\
\text { sponse indicators combined with corresponding market } \\
\text { prices. }\end{array}$ \\
\hline Substitution method & $\begin{array}{l}\text { Takes into account prices and costs of acceptable substitutes } \\
\text { for environmental goods and resources which are threat- } \\
\text { ened or have been lost. }\end{array}$ \\
\hline Restoration method & $\begin{array}{l}\text { Specifies the cost of actions that must be taken to restore } \\
\text { or reclaim environmental resources (restore their original } \\
\text { value). }\end{array}$ \\
\hline Prevention method & $\begin{array}{l}\text { Specifies the cost of actions that must be undertaken to pre- } \\
\text { vent the destruction of certain environment resources or at } \\
\text { least reduce the effects of harmful effects. }\end{array}$ \\
\hline Compensation method & $\begin{array}{l}\text { As a starting point, takes monetary values of compensation } \\
\text { for environmental degradation awarded by legal entities or } \\
\text { insurers. }\end{array}$ \\
\hline Opportunity cost & $\begin{array}{l}\text { Represents the utility value of goods and environmental re- } \\
\text { sources on the basis of income from alternative variants of } \\
\text { discontinued use. }\end{array}$ \\
\hline
\end{tabular}

Source: [4, p. 118] based on [14, p. 89].

The use of indirect methods for determining the value of potential losses to the natural environment leads to attempts to measure their value. Table 3 presents a methodology for valuating losses on account of direct or indirect utility, as well as other characteristics such as those associated with change of the landscape. Based on this, using a survey (which may include the willingness to pay for avoiding loss or willingness to accept compensation) for example, attempts 
are made to estimate the actual loss of utility and alternative values of various elements of the natural environment resulting from externalities associated with electricity generation as shown in Table 3 .

\section{Table 3}

Methodology for measuring the value of losses resulting from electricity generation

\begin{tabular}{|c|c|}
\hline Method & The essence of the evaluation \\
\hline Categorize value & $\begin{array}{l}\text { Direct or indirect use value, such as value of power plant con- } \\
\text { struction sites. } \\
\text { - Non-usable value (liabilities), such as changes in the landscape. } \\
\text { - Total economic value: } \\
\text { - actual usable value, } \\
\text { - alternative value of the natural environment. }\end{array}$ \\
\hline Measures of value & $\begin{array}{l}\text {-Willingness To Pay (WTP) - how much victims are willing to pay } \\
\text { to avoid the effect of externalities (e.g. particulate matter emis- } \\
\text { sions) associated with electricity generation. } \\
\text { - Willingness To Accept (WTA) compensation, for example for } \\
\text { loss of health due to mercury emissions. } \\
\text { - Consumer surplus, i.e. changes in consumer surplus due to: } \\
\text { increases in electricity prices, increased quality, changing avail- } \\
\text { ability of substitutes. } \\
\text { - Producer surplus. } \\
\text { - The value of economic consequences of: } \\
\text { - primary expenditure, } \\
\text { - indirect effects, } \\
\text { - induced effects (extra income from operations). } \\
\text { - Energy value (i.e. monetary value of energy). }\end{array}$ \\
\hline $\begin{array}{l}\text { Valuation methods } \\
\text { (techniques), } \\
\text { including: } \\
\text { - direct and } \\
\text { - market based } \\
\text { ones }\end{array}$ & $\begin{array}{l}\text { - Cost-benefit analysis (CBA). } \\
\text { - Method of minimizing cost (MMC). } \\
\text { - Valuating effects on production (EP). } \\
\text { - Valuating preventive expenditures (PE) and the costs of restitu- } \\
\text { tion (COR). } \\
\text { - Valuating human capital (disease cost (DC) method). } \\
\text { - Method of declared preferences (DP). } \\
\text { - Method of transfer values (TV). } \\
\text { - Indicators of losses per unit of product. }\end{array}$ \\
\hline
\end{tabular}

Source: based on [4, p. 119]

The preferred method is to measure economic consequences but in practice social losses are often not compensated and there is no consensus in literature on the appropriate method of their valuation. Therefore, currently externalities 
associated with the operation of power and cogeneration plants in a large part do not have economic consequences, except for expenditures associated with investments in exhaust gas purification systems or in the form of penalties for exceeding emission limits.

\section{Reducing External Costs in the Domestic Electric Power Industry}

In practice, determining external costs, and subsequently social costs that are the sum of private and external costs, requires the collection of large amounts of data. The collection of information necessary to determine the level of external costs of electricity generation shown in Table 4. These include the quantity and structure of negative effects of the generating process, capital investments to eliminate the negative consequences of the process, quantity and structure of damage and losses caused by negative processes, and on this basis, the calculation of external costs per unit of electric energy.

Table 4

Information required to determine the external costs of electricity generation

\begin{tabular}{|l|l|l|l|}
\hline \multicolumn{1}{|c|}{ Category } & \multicolumn{1}{|c|}{ Economic content } & $\begin{array}{l}\text { Information required } \\
\text { to quantify }\end{array}$ & Availability \\
\hline $\begin{array}{l}\text { Quantity and } \\
\text { structure of } \\
\text { negative effects } \\
\text { of the process. }\end{array}$ & $\begin{array}{l}\text { Quantity and value } \\
\text { of individual negative } \\
\text { effects. }\end{array}$ & $\begin{array}{l}\text { Detailed list of the } \\
\text { quantity and value of } \\
\text { negative effects of the } \\
\text { process according to } \\
\text { its various phases. }\end{array}$ & Incomplete \\
\hline $\begin{array}{l}\text { Capital } \\
\text { expenditure } \\
\text { to eliminate } \\
\text { negative effects } \\
\text { of the process. }\end{array}$ & $\begin{array}{l}\text { Total capital expenditures } \\
\text { on eliminating negative } \\
\text { effects of the process } \\
\text { divided according to the } \\
\text { function of objects and } \\
\text { distinguished phases. }\end{array}$ & $\begin{array}{l}\text { Detailed list of the } \\
\text { type of expenditure } \\
\text { to restore damaged } \\
\text { parts of the natural } \\
\text { environment. }\end{array}$ & Incomplete \\
\hline $\begin{array}{l}\text { Quantity and } \\
\text { structure of } \\
\text { damage and } \\
\text { losses caused } \\
\text { by adverse } \\
\text { processes. }\end{array}$ & $\begin{array}{l}\text { Value of used and not } \\
\text { reconstructed elements of } \\
\text { the natural environmental } \\
\text { divided according to the } \\
\text { phases of the process. }\end{array}$ & $\begin{array}{l}\text { Quantification and } \\
\text { prices of damaged } \\
\text { parts of the natural } \\
\text { environment. }\end{array}$ & Incomplete \\
\hline
\end{tabular}


Tabela 4 cont.

\begin{tabular}{|l|l|l|l|}
\hline $\begin{array}{l}\text { Total } \\
\text { expenditures } \\
\text { on eliminating } \\
\text { negative } \\
\text { effects of the } \\
\text { processes }\end{array}$ & $\begin{array}{l}\text { All expenditures on } \\
\text { reconstructing damaged } \\
\text { parts of the natural } \\
\text { environment. }\end{array}$ & $\begin{array}{l}\text { Value of expenditures } \\
\text { according to their } \\
\text { structure and phases of } \\
\text { the process. }\end{array}$ & Incomplete \\
\hline $\begin{array}{l}\text { Total external } \\
\text { costs of } \\
\text { eliminating } \\
\text { negative effects } \\
\text { of the process. }\end{array}$ & $\begin{array}{l}\text { Value of factors } \\
\text { of production required } \\
\text { to mitigate the negative }\end{array}$ & $\begin{array}{l}\text { effects of the process. } \\
\text { in the process of } \\
\text { recreating destroyed } \\
\text { elements of the natural } \\
\text { environment. }\end{array}$ & Incomplete \\
\hline $\begin{array}{l}\text { Products } \\
\text { obtained in } \\
\text { the process } \\
\text { of eliminating } \\
\text { negative } \\
\text { effects. }\end{array}$ & $\begin{array}{l}\text { Quantity and value } \\
\text { of the results that were } \\
\text { obtained. }\end{array}$ & $\begin{array}{l}\text { Detailed list of } \\
\text { quantities and values } \\
\text { according to the } \\
\text { phases of the process } \\
\text { and the type of } \\
\text { products that were } \\
\text { obtained. }\end{array}$ & Incomplete \\
\hline $\begin{array}{l}\text { External } \\
\text { costs of each } \\
\text { product. }\end{array}$ & $\begin{array}{l}\text { The value of factors } \\
\text { of production required } \\
\text { to eliminate the negative } \\
\text { effects of electricity } \\
\text { generation. }\end{array}$ & $\begin{array}{l}\text { Amount of products } \\
\text { obtained in the process } \\
\text { and total external } \\
\text { costs of factors of } \\
\text { production used in } \\
\text { specific processes. }\end{array}$ & Incomplete \\
\hline
\end{tabular}

Source: based on [11, pp. 77-79]

In Poland, there are three ways of limiting emissions in the electricity generation industry (see Table 5). The first one implies a reduction of domestic production and increasing imports. This is currently not viable because of rising demand and limited cross border transmission capacity. The second one would involve retrofitting pollution control devices, such as scrubbers, on existing plants. This solution is already largely in place but the construction of new, expensive emission control systems in some old, worn out power plants is uneconomic. The third option is to build new power and combined heat and power (CHP) plants.

Current achievements in the theory and practice of environmental economics and management systems shows that problems related to environmental protection cannot be easily resolved by market-based methods alone and state intervention becomes necessary [3, p. 211]. 
Table 5

Emission reduction options in the Polish electric power industry

\begin{tabular}{|c|c|c|}
\hline Option & Benefits & Disadvantages \\
\hline $\begin{array}{l}\text { 1. Reducing } \\
\text { domestic } \\
\text { generating } \\
\text { capacity }\end{array}$ & $\begin{array}{l}\text { No need for large capital expendi- } \\
\text { ture. } \\
\text { - No need to make strategic decisions } \\
\text { involving financial commitments. }\end{array}$ & $\begin{array}{l}\text { - In the case of sustained or } \\
\text { increased demand for elec- } \\
\text { tricity, retiring existing plants } \\
\text { would necessitate imports of } \\
\text { clean energy from abroad. } \\
\text { - Reliance on imports may in- } \\
\text { crease electricity cost (high } \\
\text { energy prices result in loss } \\
\text { of competitiveness of goods } \\
\text { produced in a country, lack of } \\
\text { progress and potentially down- } \\
\text { fall of domestic industry.) }\end{array}$ \\
\hline $\begin{array}{l}\text { 2. Retrofitting } \\
\text { pollution } \\
\text { control } \\
\text { devices on } \\
\text { existing } \\
\text { plants }\end{array}$ & $\begin{array}{l}\text { - Initially low (compared with option } \\
\text { 3) cost of meeting EU requirements } \\
\text { by adding desulphurization and de- } \\
\text { nitrification facilities to existing po- } \\
\text { wer units. } \\
\text { - Keeping domestic sources of elec- } \\
\text { tricity generation which increases } \\
\text { energy security and provides work } \\
\text { for power engineers, miners and } \\
\text { energy industry supply companies. } \\
\text { - After old power units are decommis- } \\
\text { sioned, pollution control systems } \\
\text { can be used for units built in place } \\
\text { of the old ones (provided the units } \\
\text { are replaced in kind). }\end{array}$ & $\begin{array}{l}\text { - For old power and cogenera- } \\
\text { tion plants, new pollution con- } \\
\text { trol devices would not extend } \\
\text { their technical lifetime and } \\
\text { may thus be uneconomical. } \\
\text { - Need to incur higher capital } \\
\text { investments than in option } 1 . \\
\text { - Need to raise electricity prices } \\
\text { in order to obtain capital for } \\
\text { pollution control devices. }\end{array}$ \\
\hline $\begin{array}{l}\text { 3. Restoring } \\
\text { power } \\
\text { generating } \\
\text { capacity } \\
\text { using new } \\
\text { technology }\end{array}$ & $\begin{array}{l}\text { - Access to the best technologies with } \\
\text { higher generating efficiencies. } \\
\text { - Opportunity for rebuilding of worn } \\
\text { out electricity generating industry } \\
\text { assets. } \\
\text { - Improved technical level of services } \\
\text { providing export opportunities. } \\
\text { - Promotes technological progress } \\
\text { and development of modern tech- } \\
\text { nologies in the country. } \\
\text { - Improves energy security - increases } \\
\text { supply reliability and provides fuel } \\
\text { savings. }\end{array}$ & $\begin{array}{l}\text { - The most capital intensive op- } \\
\text { tion. } \\
\text { - May cause an increase in elec- } \\
\text { tricity prices. } \\
\text { - Difficulties in obtaining finan- } \\
\text { cial capital if electricity de- } \\
\text { mand decreases. }\end{array}$ \\
\hline
\end{tabular}

Source: based on [5, pp. 95-96] 
In practice, four ways of correcting market inefficiencies to reduce externalities associated with environmental pollution caused by the energy industry are in use: Pigouvian tax - assumed to correspond to the magnitude of marginal external costs, quantitative restrictions on production (such as tradable emission rights) as well as the allocation of property rights and subsidies [3, p. 213].

The following instruments play an important role in reducing externalities:

- emission charges: for introducing gases and particulate matter into the air or sewage into the water and land, for waste storage, monetary deposits (e.g. when buying batteries containing lead), product based (e.g. on the purchase of products containing ozone depleting substances),

- penalty for exceeding permissible noise levels,

- security claims for negative effects on the natural environment,

- liability insurance for damage caused by oil spills or for nuclear damage,

- aid, including: grants, preferential loans, tax preferences,

- market for tradable greenhouse gas emission permits [3, pp. 215-217].

The aforementioned ways of correcting inefficiencies in the market and the natural environment are aimed at ensuring the sustainable development of the electric power industry, despite the partial loss of government control over its development as a result of the introduction of market mechanisms in the process of privatization and deregulation in accordance with EU guidelines.

There are three basic ways of accounting for external costs: the polluter pays principle (PPP), cost sharing by the emitter and the harmed party, transferring external costs on the consumer by including them in product prices. External costs are included in social costs that consist of two main components: direct costs and external costs of producers expressing expenditures by other entities due to the production process $[3, \mathrm{pp} .74,82]$. In order to determine these costs, it is necessary to estimate prices of parts of the natural environment on the basis of the social costs of acquisition and preservation, according to the following equation [10, pp. 58, 84]:

$$
c_{\text {soc }}=c_{\text {prod. }}+c_{\text {ext }}
$$

gdzie:

$$
\begin{aligned}
& c_{s o c}-\text { social cost, } \\
& c_{p r o d}-\text { direct producer's cost, } \\
& c_{\text {ext. }}-\text { external cost. }
\end{aligned}
$$

There is also the issue of real parameters of power plants using renewable energy sources (RES) being largely dependent on natural processes. The amount of electricity produced is often variable, depending on the time of day and year as well as changes from year to year since the amount of water and biomass, wind speed, solar radiation and (subsequently) volume of production, are subject to 
frequent, partly unpredictable changes. Due to the stochastic nature of production from such plants, costs of alternative energy sources should be taken into account [9]. They can be estimated according to the following equation [16, p. 38]:

gdzie:

$$
K_{B U}=\frac{A_{K}}{b_{V}}-\frac{A_{K} L}{b_{W}}=A_{K}\left(\frac{1}{b_{V}}-\frac{L}{b_{W}}\right)
$$

$A_{K}-$ annual fixed cost of replacement energy sources (per $\mathrm{kW}$ of generating capacity),

$b_{V}$ - number of hours when alternative sources are used,

$\boldsymbol{b}_{W}$ - number of hours when used, including renewable energy,

$L$ - possible subsidy for the use of RES.

The magnitude of the cost of replacement energy sources must be determined individually for each source and can be estimated based on data from prior periods for such plants. In addition, different types of power and cogeneration plants, including those burning hydrocarbons, using nuclear power and renewables, have an uneven impact on the natural environment, which generates different external costs.

Due to the difficulties in establishing actual external costs, environmental pollution costs are widely regarded as a measure of the losses to the natural environment caused by the activities of economic entities. This approach is flawed since these fees and penalties may not be a good measure of losses because they do not express the value of damaged parts of the natural environment [11, pp. 57-59]. However, due to a lack of consensus in literature regarding the proper methodology for determining the value of losses to the natural environment, this paper adopted fees and penalties as proxies for external costs, which is also consistent with the generally accepted principle of reliance on cash accounting. In connection with the pursuit of the European Union's legislation to internalize costs, i.e. the conversion of external costs to firm's internal costs, along with advances in methods of assessment and evaluation of damage caused by the emission of harmful substances, this approach should increasingly accurately correspond to the actual losses to the natural environment.

\section{Determining the effect of $\mathrm{CO}_{2}$ emission allowances and green certificates on the unit cost of electricity generation}

Another object of analysis is the impact of $\mathrm{CO}_{2}$ emissions on the unit cost of electricity generation as shown in Figure 1. Eligibility for $\mathrm{CO}_{2}$ emissions allowances does not affect the cost of generating electricity in nuclear power plants 
and wind farms because they do not emit this gas. In terms of pricing emission allowances from zero to $400 \mathrm{zl}$ in this analysis, electricity from wind power plants has the lowest cost due to subsidies in the form of green certificates. Assuming free emission allowances (i.e. their nonexistence), electricity from coal-fired plants is the second cheapest in terms of cost of production, whereas gas-fired power plants are the third least expensive.

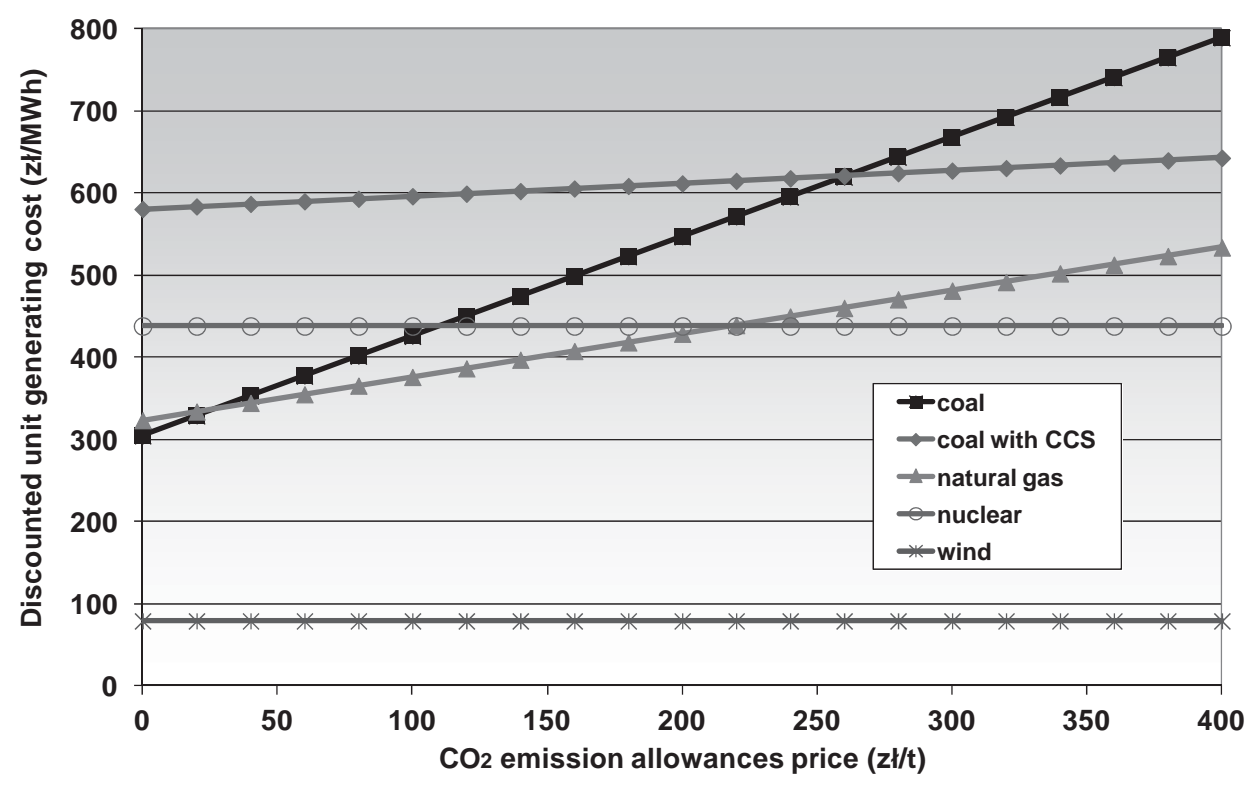

Figure 1. Discounted unit electricity generating cost as a function of $\mathrm{CO}_{2}$ emission allowances price

Source: own calculations based on data from $[1$, p. $6 ; 6$, p. $24 ; 7$, p. 103,$186 ; 8$; 13, pp. I-62, II-9, II-23, II-30, II-36; 15, s. 81]

When the price of $\mathrm{CO}_{2}$ emission allowance exceeds $10 \mathrm{zt} /$ metric ton, natural gas-fired power plants are the second cheapest source of electricity. Further increases in the price of allowances increases the difference in the cost of generating electricity using wind turbines and nuclear fuel, and power plants emitting $\mathrm{CO}_{2}$. An increase in the price of $\mathrm{CO}_{2}$ emission allowances has the greatest impact on coal-fired power plants without $\mathrm{CO}_{2}$ storage system due to the highest level of emissions of this gas from such plants. Therefore, introduction of $\mathrm{CO}_{2}$ emission allowances strongly favors power plants that are not combustion based, such as nuclear power plants and those using RES. 
Green certificates, i.e. tradable commodities proving that a certain amount of electricity was generated from RES, constitute a slightly different direction of economic and social activities aimed at environmental protection. A strategy to support electricity generation from these sources in Poland includes an obligation on suppliers to purchase $10,4 \%$ of electricity from RES in 2012 (this includes a forecasted increase in this requirement in accordance with draft regulations by the Minister of Economy [12]).

Figure 2 shows a relation between the price of green certificates, applied to support renewable energy use, and the cost of electricity generation. It should be noted that these results are directly related to prices of green certificates set by the Polish government. They are a source of additional revenue for wind power (or other RES based) producers whereas they are a cost for other electricity generation technologies.

For all types of plants, except for the wind powered ones, producers are required to buy additional green certificates, which increases generating costs. In the case of a wind power, green certificates are obtained for the total production and their excess can be sold on the market. Therefore, increases in the price of green certificates significantly reduce the cost of electricity generation in this type of plants.

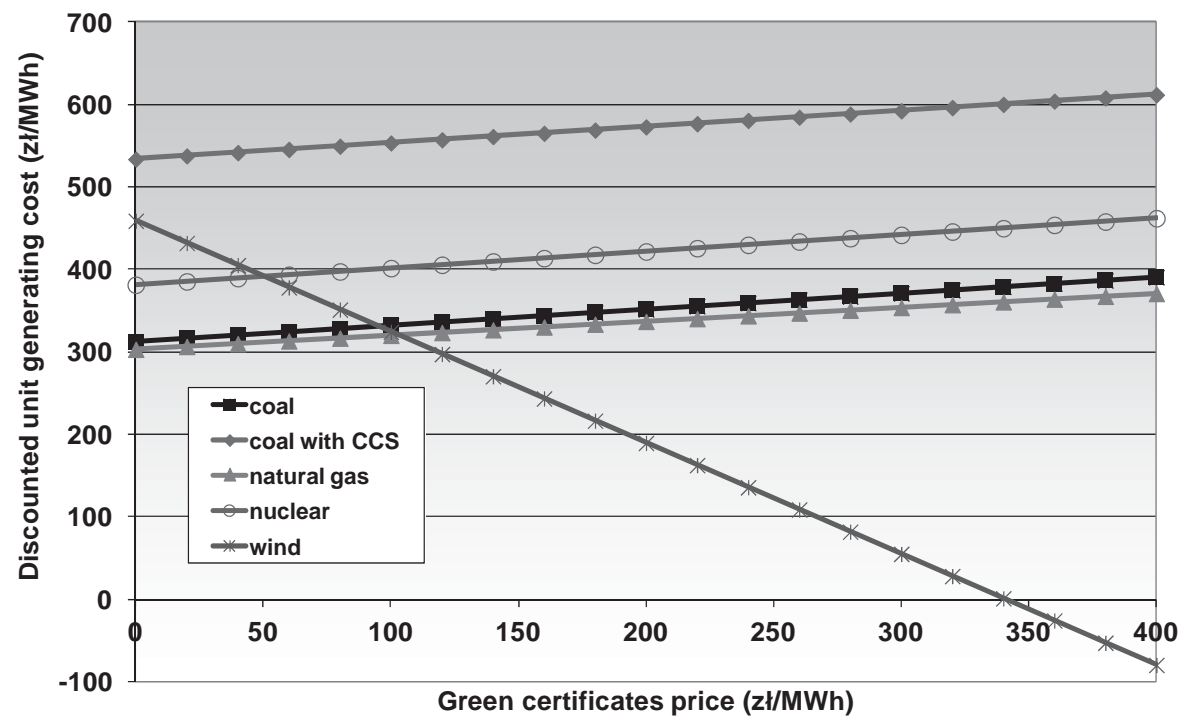

Figure 2. Discounted unit electricity generating cost as a function of green certificates price

Source: own calculations based on data from $[1$, p. 6; 6, p. 24; 7, pp. 103, 186; 8; 13, pp. I-62, II-9, II-23, II-30, II-36; 15, p. 81] 


\section{Summary}

The analysis carried out and presented in this paper leads to the following conclusions:

1. An analysis of the theory and practice shows a need for a methodology for assessing external costs in the energy industry in general and the electricity generation industry in particular.

2. Estimation of external costs in the energy industry is difficult due to complicated cause and effect relationships, particularly in the effect of low concentrations of pollutants on the natural environment and the quality of human life.

3. Emissions of harmful substances (such as nitrogen and sulfur oxides, particulate matter, mercury and waste, including radioactive waste) associated with electricity generation can be relatively easily quantified in physical units, but valuation of the damage caused by them is much more difficult.

4. To value losses to the natural environment, it is necessary to use indirect methods based on: attempted market valuation of losses, cost of substitutes for threatened or lost property, replacement and prevention costs, compensation, or a valuation of lost opportunities.

5. In practice, four ways of correcting market inefficiencies and reducing externalities associated with environmental pollution caused by the energy industry are in use: Pigouvian taxes - assumed to correspond to the magnitude of marginal external costs, quantitative restrictions on production (e.g. transferable emissions rights) and allocation of property rights and subsidies.

6. Mechanisms aimed at reducing environmental pollution and increasing the use of renewable energy sources, such as $\mathrm{CO}_{2}$ emission rights and green certificates, significantly reduce the relative cost of generating electricity from renewable energy sources.

\section{References}

[1] Anderson D., Electricity Generation and Investment Decisions: A Review, UKERC, London 2007.

[2] Bickel P., Environmental External Costs and International Experience with the Internalization, Institut für Energiewirtschaft und Rationelle Energieanwendung, Universität Stuttgart 2007.

[3] Borys G., Finansowe instrumenty ochrony środowiska przed zanieczyszczeniem, in: Pietrzak B. (ed.), Finanse (monografie $i$ opracowania naukowe), Szkoła Główna Handlowa, Warszawa 2005.

[4] Famielec J., Straty i korzyści ekologiczne w gospodarce narodowej, WN PWN, Warszawa-Kraków 1999. 
[5] Famielec J., System finansowania ochrony środowiska $w$ Polsce $w$ warunkach integracji z Unia Europejska, Wydawnictwo Akademii Ekonomicznej, Kraków 2005.

[6] Friedrich R., External and social costs of electricity generation, Institut für Energiewirtschaft und Rationelle Energieanwendung, Universität Stuttgart, Erice 2008.

[7] International Energy Agency (IEA), Nuclear Energy Agency (NEA), Organization for Economic Cooperation and Development (OECD), Projected Costs of Generating Electricity, IEA, NEA and OECD, Paris 2010.

[8] Korab R., Wplyw wybranych aspektów polityki klimatycznej UE na prace krajowego systemu elektroenergetycznego, „Rynek Energii” nr 2/2011, http://www.cire.pl/pdf.php?plik=/pliki/2/wpl_pol_klimue_prac_syst.pdf (2011.07.01).

[9] Kruck C., Ludger E., Stromerzeugung aus erneuerbaren Energien - Eine technische, ökonomische und ökologische Analyse im Hinblick auf eine nachbaltige Energieversorgung in Deutschland, Institut für Energiewirtschaft und Rationelle Energieanwendung (IER), Universität Stuttgart 2004.

[10] Księżyk M., Racjonalne gospodarowanie pierwotnymi nośnikami energii w Polsce, CPPGSMiE PAN, Kraków 1989.

[11] Księżyk M., System kosztów. Metodyka ustalania kosztów (na przykładzie procesów pozyskiwania węgla kamiennego w Polsce), Księgarnia Akademicka, Kraków 1994.

[12] Ministerstwo Gospodarki, Rozporzadzenie Ministra Gospodarki w sprawie szczegótowego zakresu obowiązów uzyskania $i$ przedstawienia do umorzenia świadectw pochodzenia, uiszczenia opłaty zastepczej, zakupu energii elektrycznej $i$ ciepla wytworzonych $w$ odnawialnych źródtach energii oraz obowiazku potwierdzania danych dotyczacych ilości energii elektrycznej wytworzonej $w$ odnawialnym źródle energii (Projekt z dnia 17.02.2011), 2011.

[13] National Energy Technology Laboratory (NETL), Investment Decisions for Baseload Power Plants, NETL, Pittsburgh 2010.

[14] Śleszyński J., Przeglad polskich oszacowań strat spowodowanych degradacja środowiska, in: Ekonomiczna wycena środowiska przyrodniczego, Anderson G., Śleszyński J. (ed.), Wydawnictwo Ekonomia i Środowisko, Białystok 1996.

[15] Urząd Regulacji Energetyki (URE), Biuletyn URE nr 2(76) 30 czerwca 2011, Warszawa 2011.

[16] Wissel S., Rath-Nagel S., Blesl M., Fahl U., Voß A., Stromerzeugungs-kosten im Vergleich, Institut für Energiewirtschaft und Rationelle Energieanwendung (IER), Universität Stuttgart, Stuttgart 2008. 